\title{
Effects of Bacillus subtilis biocementation on the mechanical properties of mortars
}

\section{Efeitos da biocimentação promovida por Bacillus subtilis nas propriedades mecânicas de argamassas}
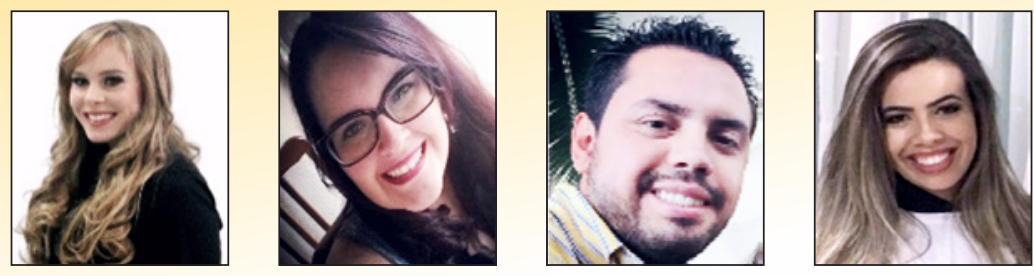

N. SCHWANTES-CEZARIO a
nicoleschwantes@hotmail.com
https://orcid.org/0000-0002-3254-6396

M. F. PORTO a mfeernanda.porto@hotmail.com https://orcid.org/0000-0002-9313-1215

G. F. B. SANDOVAL

gersson.barreto@gmail.com
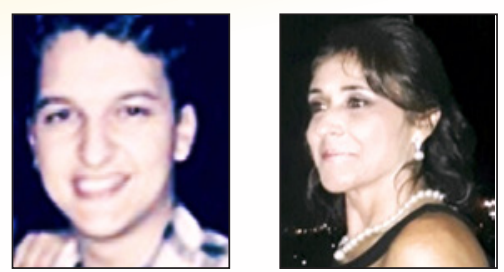

G. F. N. NOGUEIRA a geovanasouzanogueira@gmail.com https://orcid.org/0000-0002-7059-257X

A. F. COUTO

alissoncouto@ymail.com https://orcid.org/0000-0002-7998-7973

B. M. TORALLES a

betoralles@gmail.com

http://orcid.org/0000-0001-8828-7250

\begin{abstract}
This study aims to evaluate the influence of $B$. subtilis AP91 spores addition on the mechanical properties of mortars. B. subtilis strain AP91, isolated from rice leaves of the needle variety, which has an early cycle of production, was used at the concentration of $105 \mathrm{spores} / \mathrm{mL}$ in mortars with cement-to-sand ratio of 1:3 (by weight) and water-to-cement ratio (w/c) of 0.63 . These spores were added in two different ways: in the mixing water and by immersion in a solution containing bacterial spores. Scanning Electron Microscope (SEM) analysis showed crystals with calcium peaks on the EDS, which possibly indicates the presence of bioprecipitated calcium carbonate. The results obtained in the mechanical analysis showed that the bioprecipitation of $\mathrm{CaCO}_{3}$ by $\mathrm{B}$. subtilis strain AP91 was satisfactory, particularly when the spores were added in the mixing water, increasing the compressive strength up to $31 \%$. Thus, it was concluded that the addition of $B$. subtilis AP91 spores in the mixing water of cement mortars induced biocementation, which increased the compressive strength. This bioprecipitation of calcium carbonate may very well have other advantageous consequences, such as the closure of pores and cracks in cementitious materials that could improve durability properties, although more research is still needed on this matter.
\end{abstract}

Keywords: calcium carbonate, biocementation, B. subtilis, mechanical properties, SEM.

\section{Resumo}

Este estudo tem como objetivo avaliar a influência da adição de esporos de B. subtilis AP91 nas propriedades mecânicas de argamassas. Para tanto, a bactéria $B$. subtilis AP91 isolada de folhas de arroz da variedade agulha precoce foi utilizada na concentração de $105 \mathrm{esporos} / \mathrm{mL}$ em argamassas com traço de 1:3 (em massa) e relação água/cimento (a/c) de 0,63. Os esporos bacterianos foram adicionados de duas diferentes formas: na água de amassamento e por imersão em solução contendo os esporos. A análise por Microscopia Eletrônica de Varredura (MEV) com Sistema de Energia Dispersiva (EDS) mostrou cristais com picos de cálcio, o que possivelmente indica a presença de carbonato de cálcio bioprecipitado. Os resultados obtidos a partir da análise mecânica mostraram que a bioprecipitação de $\mathrm{CaCO}_{3}$ pela bactéria $\mathrm{B}$. subtilis AP91 foi satisfatória, particularmente quando os esporos foram adicionados à água de amassamento, aumentando a resistência à compressão em até $31 \%$. Portanto, conclui-se que a adição de esporos de B. subtilis AP91 na água de amassamento das argamassas induziu a biocimentação, que aumentou a resistência à compressão. A bioprecipitação de carbonato de cálcio pode ter outras consequências benéficas, como o fechamento de poros e fissuras em materiais cimentícios, que poderiam melhorar a durabilidade, embora mais pesquisas neste aspecto ainda sejam necessárias.

Palavras-chave: carbonato de cálcio, biocimentação, B. subtilis, propriedades mecânicas, MEV.

State University of Londrina, Department of Building Construction, Londrina, PR, Brazil.

Received: 04 Aug 2017 • Accepted: 07 May 2018 • Available Online:

This is an open-access article distributed under the terms of the Creative Commons Attribution License 


\section{Introduction}

Except for water, the cementitious materials are the most consumed substances on Earth [1]. Because of that, they should be studied to present satisfactory performance and, for that matter, several works are being performed nowadays to improve the mechanical properties of such materials.

In view of the growing concern about improving the characteristics and durability of cementitious materials, additions of bacteria, mainly of the genus Bacillus, are being studied for crack filling and increasing of the compressive strength through calcium carbonate $\left(\mathrm{CaCO}_{3}\right)$ precipitation [2]. Because of that, the bioprecipitation of $\mathrm{CaCO}_{3}$ by bacteria in cementitious materials is also called biocementation [4].

It should be noted that bacteria already exist for billions of years, however many of their biotechnological applications are not yet widespread [5]. Although many researchers are interested in the bioprecipitation of $\mathrm{CaCO}_{3}$, the whole process is not yet clear and defined. Once the bacteria can precipitate calcium carbonate through several mechanisms, the physiology and genetic involved are complex and difficult to understand [6], [7], [8].

Some bacteria that have the ability of producing minerals were used to repair limestone monuments [9], [10], [11], [12], [13] [14] and to fill pores and cracks in concrete and other cementitious materials [5], [8], [15], [16], [17], [18], which can improve their mechanical properties and durability.

Among the bacteria used in researches about biocementation, the bacteria $B$. subtilis stand out. These bacteria can produce calcite, a crystalline form of $\mathrm{CaCO}_{3}$, which is precipitated when they're exposed to a medium with a calcium source [25], [26], [27]

The biocementation can be induced by two ways of addition of bacteria: in the mixing water of mortars [1] [3], [15], [19], [22], [28], [29] or by immersion of the specimens in a solution containing bacteria [18], [30]. However, the studies that confront these two ways of bacteria addition are rare, so that researches comparing both are important.

The aim of this study was to evaluate the influence of biocementation, induced by two different ways of spores addition, on the mechanical properties of mortars. Thus, the spores of bacteria $B$. subtilis strain AP91 were used.

\section{Materials and methods}

\subsection{Bacteria and growth conditions}

B. subtilis AP91, isolated in Brazil from rice leaves of the early cycle needle variety, was used [31]. To achieve the required concentration, the bacterium was incubated in a Luria-Bertani (LB) medium under agitation of $170 \mathrm{rpm}$ at $37^{\circ} \mathrm{C}$ for 48 hours. The medium was poured into $15 \mathrm{~mL}$ polystyrene tubes, which were centrifuged at $4,000 \mathrm{rpm}$ and $23^{\circ} \mathrm{C}$ for 3 minutes, in order to separate the bacterial cells from the growing medium. The supernatant was discarded and the pellet containing the bacterial cells was re-suspended in a phosphate buffer solution, homogenized and centrifuged again. This procedure was performed four times.
The obtained concentration was quantified in a spectrophotometer with a reading of $600 \mathrm{~nm}$, from the Equation 1 described by [15]:

$X=8.59 \cdot 10^{7} \cdot Y^{1.3627}$

Where $X$ is the concentration in cells $/ \mathrm{mL}$ and $Y$ is the reading of the spectrophotometer at $600 \mathrm{~nm}$.

From the found concentration, the dilution calculations were made in order to achieve a concentration of $10^{5} \mathrm{cells} / \mathrm{mL}$. The dilution was made in a phosphate buffer solution, then stored at $8^{\circ} \mathrm{C}$ for 48 hours for the spores formation.

\subsection{Mortars}

The mortars were produced using:

- Portland cement (CP-II E-32, Brazilian denomination);

- Quartz fine sand: fineness modulus of 1.51 , maximum size of $1.18 \mathrm{~mm}$ and specific gravity of $2.604 \mathrm{~g} / \mathrm{cm}^{3}$;

- Potable water;

- Phosphate buffer solution: $1.05 \mathrm{~g} / \mathrm{L}$ dibasic-anhydrous sodium phosphate $(0.07 \%$ of the cement bulk), $0.36 \mathrm{~g} / \mathrm{L}$ monobasic sodium phosphate $(0.02 \%$ of the cement bulk) and $8.17 \mathrm{~g} / \mathrm{L}$ sodium chloride $(0.51 \%$ of the cement bulk);

B. subtilis AP91.

The spores of bacteria, in a concentration of $10^{5}$ spores $/ \mathrm{mL}$, were added to the mixture in two different ways: in the mixing water and by immersion in a phosphate buffer solution containing the spores. For that, four variations of mortars were produced in this study; the nomenclature and composition of those are presented in Table 1. The cement-to-sand ratio used was 1:3, by weight, and the bacterial culture or water-to-cement ratio $(\mathrm{w} / \mathrm{c})$ was kept at 0.63 . The mixture proportions are shown in Table 2.

\subsection{Experimental methods}

The microstructure of the mortars was evaluated by Scanning Electron Microscopy (SEM) and Energy Dispersive System (EDS). In these analysis it was found crystals of calcium carbonate $\left(\mathrm{CaCO}_{3}\right)$ in the mortars with addition of spores. In order to evaluate the influence of $\mathrm{CaCO}_{3}$ crystals on the mechanical properties of mortars, all of them were tested by compressive strength, indirect tensile strength (Brazilian test) and dynamic modulus of elasticity.

\section{Table 1}

Nomenclature of the mortars

\begin{tabular}{cr}
\hline Mortars & $\begin{array}{c}\text { Composition of mortars } \\
\text { REF_WT }\end{array}$ \\
SP_IM* & $\begin{array}{r}\text { Reference mortar produced with water: } \\
\text { cement, sand and water. }\end{array}$ \\
REF_PB & $\begin{array}{r}\text { Reference mortar produced with phosphate } \\
\text { cement, sand and water. } \\
\text { buffer: cement, sand and phosphate buffer. } \\
\text { Mortar with addition of spores in the mixing }\end{array}$ \\
SP_MW & $\begin{array}{r}\text { Water: cement, sand and phosphate buffer with } \\
\text { 105 spores } / \mathrm{mL} .\end{array}$ \\
\hline * Spores were added during the curing time, when this mortar was submerged \\
in a tank with phosphate buffer with a concentration of 105 spores/mL.
\end{tabular}


Table 2

Mixture proportions

\begin{tabular}{cccccc}
\hline Mortars & Cement $(\mathrm{g})$ & Sand $(\mathrm{g})$ & Water $(\mathrm{mL})$ & Phosphate buffer $(\mathrm{mL})$ & Spores of $\boldsymbol{B}$. subtilis/mL \\
\hline REF_WT & 2362.5 & 7087.5 & 1488 & - & - \\
SP_IM & 2362.5 & 7087.5 & 1488 & - & $10^{5 *}$ \\
REF_PB & 2362.5 & 7087.5 & - & 1488 & - \\
SP_MW & 2362.5 & 7087.5 & - & 1488 & $10^{5 *}$ \\
\hline * The concentration of $10^{5}$ spores $/ \mathrm{mL}$ was dispersed in the phosphate buffer solution & &
\end{tabular}

\subsubsection{SEM analysis}

SEM was used to observe the mortar microstructure and the precipitation of calcium carbonate $\left(\mathrm{CaCO}_{3}\right)$. The microanalysis was performed using an FEI-Quanta 200
Scanning Electron Microscope with an accelerating voltage of $25 \mathrm{kV}$ for determination of the chemical elements. The mortars specimens of $10 \times 10 \times 10 \mathrm{~mm}$ had their surface covered with gold and were tested after 7 and 28 days of curing.
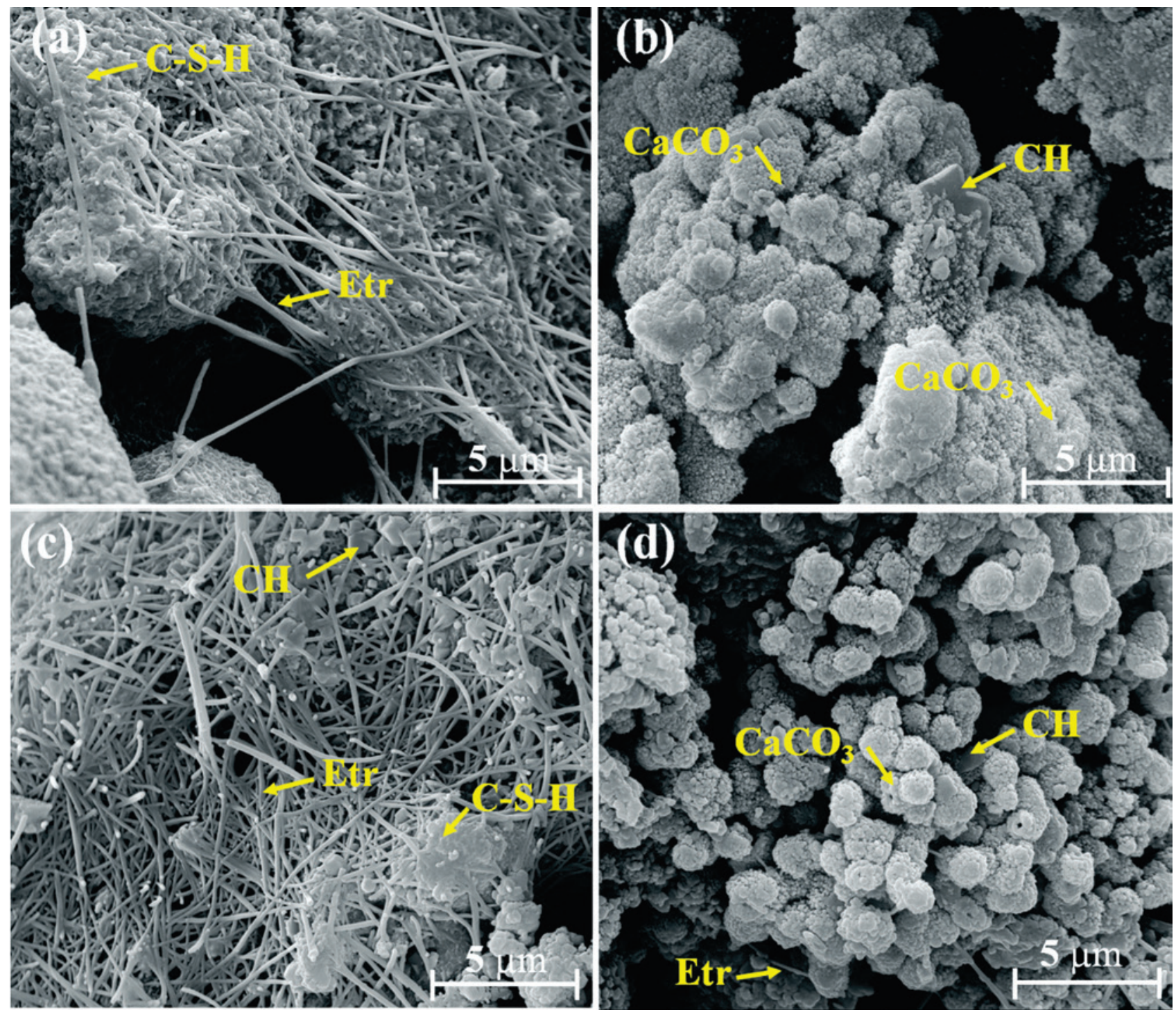

\section{Figure 1}

SEM of mortars after 7 days of curing at magnification of 12.000x. (a) REF_WT. (b) SP_IM. (c) REF_PB and (d) SP_MW 


\subsubsection{Mechanical properties of the mortars}

To study the compressive strength [32], indirect tensile strength [33] and dynamic modulus of elasticity, cylindrical specimens of $50 \mathrm{~mm}$ diameter and 100mm height were molded according to [32]. All specimens were cured by immersion at room temperature until testing after 7 and 28 days of curing. The mortars REF_WT, REF_PB and SP_MW were cured in a tank of lime-saturated water and the mortar SP_IM was cured in a tank containing a phosphate buffer solution with $10^{5}$ spores $/ \mathrm{mL}$ of $B$. subtilis AP91, also saturated with lime.

\section{Results and discussions}

\subsection{Microscopic investigation}

To search for evidence of microbial calcium carbonate precipita- tion, the mortar specimens were examined under a Scanning Electron Microscope (SEM). Fig. 1 shows a scanning electron micrograph of the mortars after 7 days of curing, in which Fig. 1(a) shows the reference mortar (REF_WT) highlighting the cement hydration products, such as calcium silicate hydrate $(\mathrm{C}-\mathrm{S}-\mathrm{H})$ and ettringite (etr). Fig. 1(b) shows the mortar with the addition of spores of $B$. subtilis strain AP91 by immersion (SP_IM), in which were highlighted the bioprecipitation of calcium carbonate $\left(\mathrm{CaCO}_{3}\right)$ can be observed. Finally, Fig. 1 (c) shows the mortar with phosphate buffer replacing water (REF_PB), where can be noted the presence of calcium hydroxide $(\mathrm{CH})$, calcium silicate hydrate $(\mathrm{C}-\mathrm{S}-\mathrm{H})$ and an intensive amount of ettringite. At last, Fig. 1(d) shows the addition of spores of $B$. subtilis in the mixing water, in which was highlighted the bioprecipitated calcium carbonate $\left(\mathrm{CaCO}_{3}\right)$.

Analyzing the SEM in Fig. 1 it can be observed that the mortars have shown the formation of cement hydration products, like

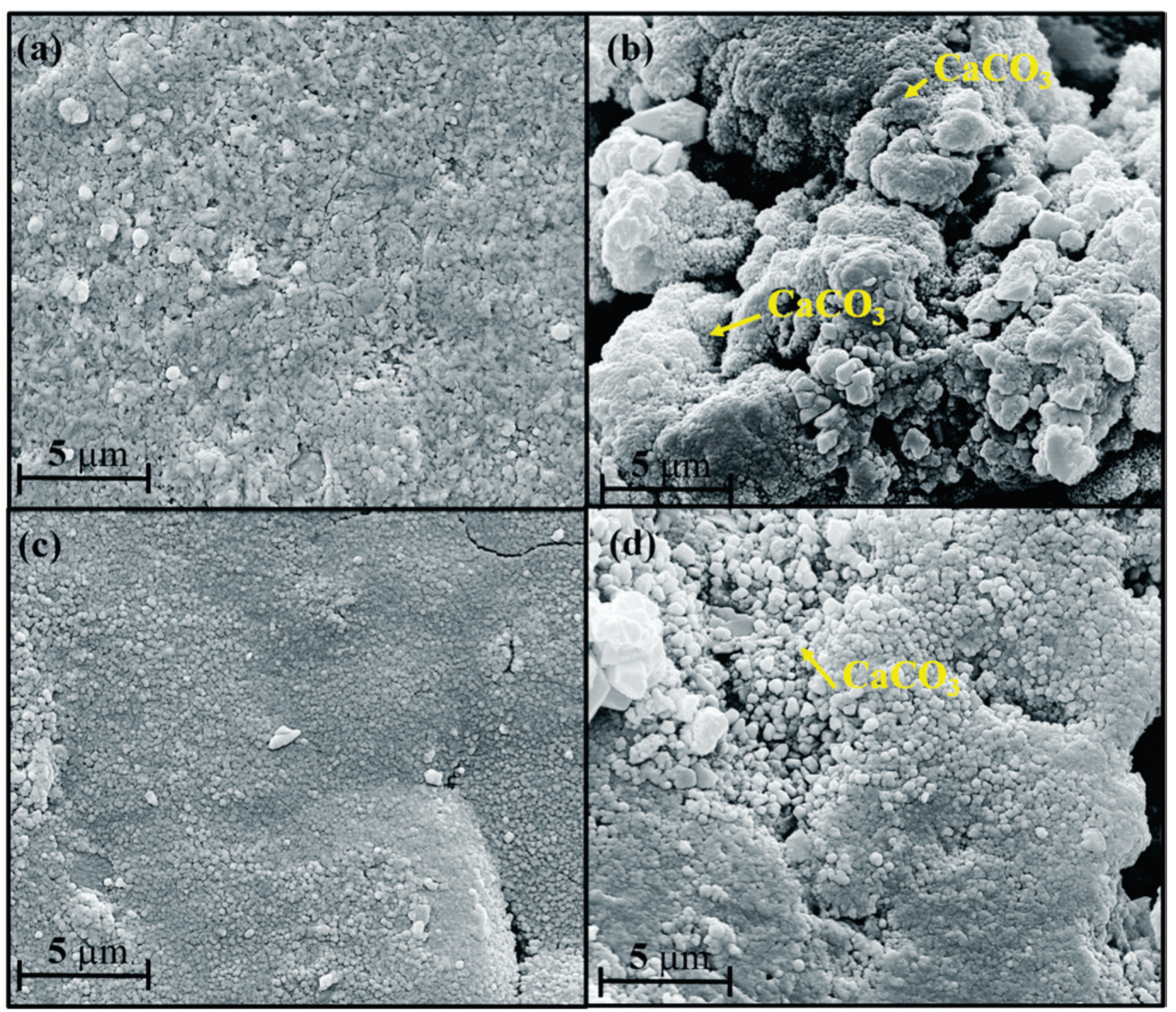

Figure 2

SEM of mortars after 28 days of curing at magnification of 12.000x. (a) REF_WT. (b) SP_IM. (c) REF_PB and (d) SP_MW 


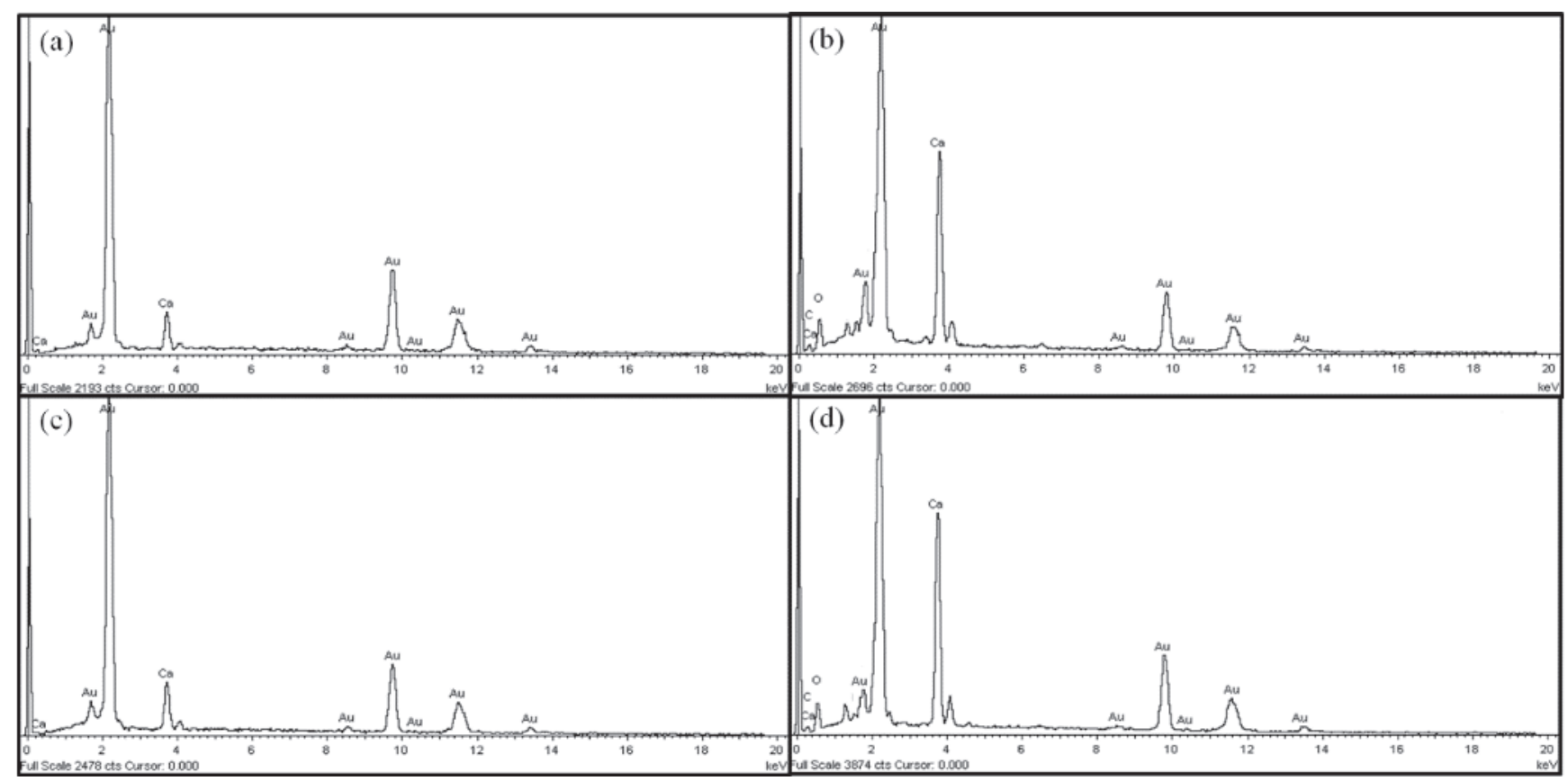

Figure 3

EDS of mortars after 28 days of curing. (a) REF_WT. (b) SP_IM. (c) REF_PB. (d) SP_MW

C-S-H, ettringite (etr) and $\mathrm{CH}$. The presence of $\mathrm{CaCO}_{3}$ was observed only in mortars with addition of $B$. subtilis spores (Fig. $1 \mathrm{~b}$ and $\mathrm{d}$ ), both by immersion and in the mixing water.

After 28 days of curing, other SEM images were taken to verify if the calcium carbonate was still present in the samples with addition of B. subtilis spores. Fig. 2 shows all mortars after 28 days of curing. Considering the images in Fig. 2, it was found the precipitation of calcium carbonate crystals only in the mortars with addition of $B$. subtilis spores (Fig. 2 b and d). After 28 days of curing, about $95 \%$ of cement is hydrated, so in these images, no hydration products can be seen. Similar crystals of $\mathrm{CaCO}_{3}$, with rounded structures, were found by Park et al. [2], Hammes et al. [6] , Braissant et al. [35], Dupraz et al. [36] and Daskalakis et al. [37].

To complete this analysis, the specimens were submitted to an Energy Dispersive System (EDS), to verify the peaks of the chemical elements present in the sample. From the EDS shown in Fig. 3 , it was observed that all mortars present peaks of calcium, but the peaks are higher when the $B$. subtilis spores have been added (Fig. $3 \mathrm{~b}$ and d). It is known that the cement has calcium, but in the mortars analyzed there was a greater presence of calcium when the spores were added, probably because the spores might have used the calcium present in cement hydration products and in the lime of the curing water to precipitate $\mathrm{CaCO}_{3}$. The greater presence of calcium indicates that the calcium carbonate crystals deposit themselves in the cement matrix (Fig. 2 b and d). Besides that, it should be noticed that the gold peaks present in all the samples are due to the coating, so that high-resolution images could be obtained.

\subsection{Compressive strength}

The medium compressive strength of different mortars $(n=5)$ after 7 and 28 days of curing are summarized in Fig. 4. The compressive strength statistically increased in the mortar specimens that contained $B$. subtilis AP91 spores added to the mixing water (SP_MW), both after 7 and 28 days of curing. When the mortar specimens were immerged (SP_IM) there were no significant

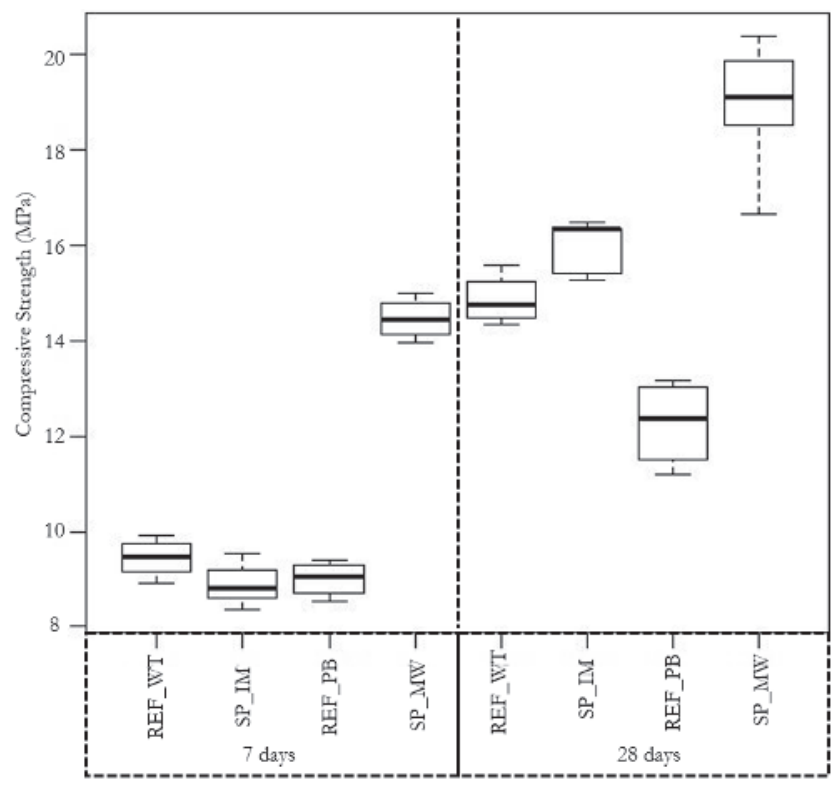

\section{Figure 4}

Effect of $B$. subtilis strain AP91 on the compressive strength of cement mortars after 7 and 28 days of curing 
differences on the compressive strength in both studied ages, compared to the control mortar (REF). That may be explained by the fact that the spores would have to penetrate the specimens to have access to the hydration products in order to react and precipitate $\mathrm{CaCO}_{3}$; moreover, the spores could find it difficult to penetrate in the specimens because of the use of release agent to mold them. Perhaps, given the sufficient amount of time and the absence of the release agent, this procedure of spores' addition could have been more efficient.

The same was found in the mortar with phosphate buffer (PB) at 7 days of curing, but at 28 days it was verified a significant decrease on the compressive strength presented by these samples. Ramachandran et al. [15] found that the addition of phosphate buffer in mortars caused better mechanical performance when compared to saline solution. However, these authors do not analyze the influence of phosphate buffer compared to a reference mortar.

It should be noticed that the results of addition of bacteria in the mixing water corroborate with what was presented in other works by Ghosh et al. [38], Reddy et al. [39], Chahal et al. [40] e Chahal and Siddique [41], who added different types of bacteria in the concentration of $10^{5}$ cells $/ \mathrm{mL}$ and found an increase on compressive strength.

The improvement in compressive strength by $B$. subtilis strain AP91 is induced by the deposition of calcium carbonate on the cell surfaces, which may have the ability of closing pores and cracks of cementitious materials [15, 42, 43, 44].

\subsection{Indirect tensile strength (Brazilian test)}

Fig. 5 shows the effect of addition of $B$. subtilis strain AP91 on the indirect tensile strength of mortars. In this test, the same tendency of the compressive strength test was verified, in which the highest indirect tensile strength, both at 7 and 28 days of curing, was found in the mortar with addition of $B$. subtilis AP91 in the mixing water. It can be pointed out that the improvement on tensile strength is consequence of the improvement of the compressive strength, since the former is usually around $10 \%$ of the latter.

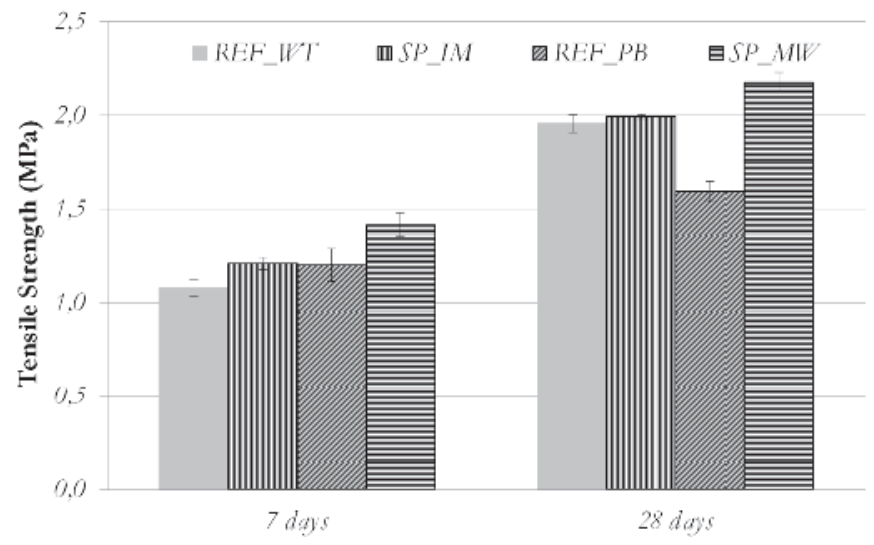

\section{Figure 5}

Effect of B. subtilis strain AP91 on the indirect tensile strength of mortars after 7 and 28 days of curing. Values are mean $\pm \mathrm{Sd}(\mathrm{n}=3)$

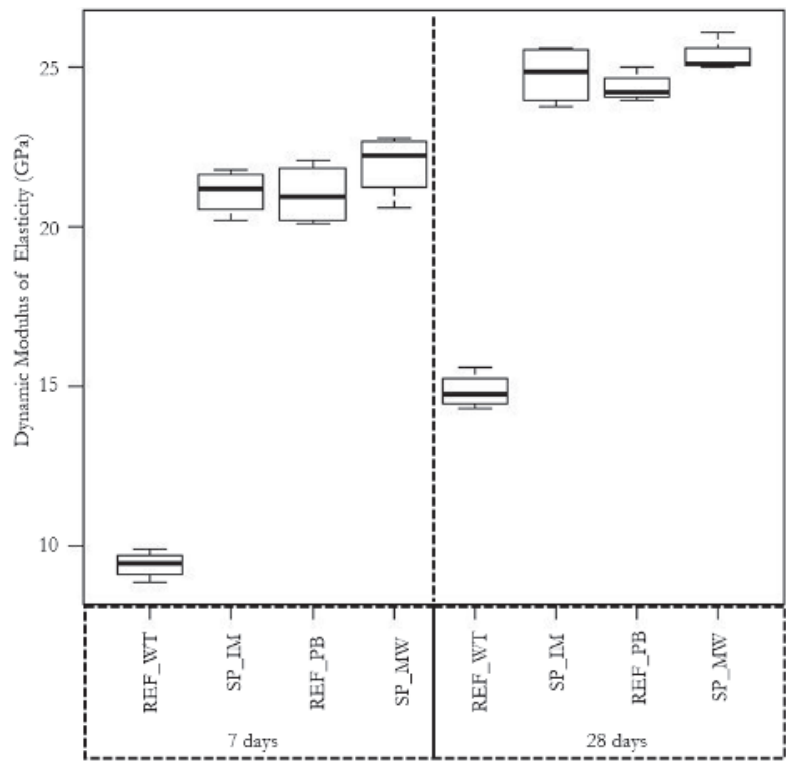

Figure 6

Dynamic modulus of elasticity of the mortars.

Values are mean $\pm \operatorname{SD}(n=5)$

\subsection{Dynamic modulus of elasticity}

The modulus of elasticity was calculated from the velocity of propagation of the ultrasonic waves, by direct transmission, through the Equation 2 described in the Brasilian standard 15630/2008 [34]. The results obtained are shown in Fig. 6 .

$E c=\frac{V^{2} x(1+\vartheta) \times(1-2 \vartheta)}{(1-\vartheta)} \times 10^{-3}$

It was verified that there was a small gradual increase in the modulus of elasticity of the mortars when were added the buffer solution and also the bacteria spores, both by immersion (SP_IM) and in the mixing water (SP_MW). It should be noticed that the mortars with the highest modulus of elasticity also corresponded to the higher strengths, for both tensile and compression. It was expected that the modulus of elasticity of the mortar containing phosphate buffer would present a lower value when compared to the reference mortar, once it also presented lower compressive strength. However, this test was performed with air-dried specimens that could still have water inside the pores, which can affect the propagation of ultrasonic waves. This could also be related to presence of salts in the buffer solution, which could have filled smaller pores in the matrix, also affecting the velocity of the ultrasonic waves.

Furthermore, the pore filling by biocementation could cause an increase in the velocity of propagation of the ultrasonic waves and, consequently, promote a higher modulus of elasticity of the specimens containing bacteria when compared to the reference.

\section{Conclusion}

- The SEM and EDS analysis verified that the addition of 
B. subtilis AP91 spores in mortars induced biocementation through the bioprecipitation of calcium carbonate crystals;

- When the spores of $B$. subtilis AP91 were added in the mixing water, they presented better mechanical performance in all tests when compared to the addition by immersion;

- B. subtilis AP91 added into mixing water has shown to be a microrganism with great potential for application in cementitious materials, since the precipitation of $\mathrm{CaCO}_{3}$ can increase both compressive and tensile strength.

- Because of the precipitation of $\mathrm{CaCO}_{3}$, the application of this microorganism for the closure of pores and fissures in cementitious materials should continue to be studied, in order to prevent early deterioration.

\section{Acknowledgments}

The authors are grateful to the State University of Londrina and to CNPq for all financial support. We also thank the Laboratory of Electron Microscopy and Microanalysis - LMEM of the State University of Londrina for the help in the analysis of SEM and EDS.

\section{References}

[1] KRISHNAPRIYA, S.; VENKATESH BABU, D. L.; PRINCE ARULRAJ G. Isolation and identification of bacteria to improve the strength of concrete. Microbiological research, v. 174,$2015 ;$ p. $48-55$.

[2] PARK, S. J.; PARK, J. M.; KIM, W. J.; GHIM, S. Y. Application of Bacillus subtilis 168 as a multifunctional agent for improvement of the durability of cement mortar. Journal of Microbiology and Biotechnology, v. 22, 2012; p. 1568-1574.

[3] ABO-EL-ENEIN, S. A.; ALI, A. H.; TALKHAN, F. N.; ABDELGAWWAD, H. A. Application of microbial biocementation to improve the physico-mechanical properties of cement mortar. HBRC Journal, v. 9, 2013; p. 36-40.

[4] ACHAL, V.; MUKHERJEE, A.; KUMARI, D.; ZHANG, Q. Biomineralization for sustainable construction-A review of processes and applications. Earth-Science Reviews, v. 148, 2015; p. 1-17.

[5] BANG, S. S.; GALINAT, J.K.; RAMAKRISHNAN, V. Calcite precipitation induced by polyurethane-immobilized Bacillus pasteurii. Enzyme and Microbial Technology, v. 28, 2001; p. 404-409.

[6] HAMMES, F.; BOON, N.; DE VILLIERS, J.; VERSTRAETE, W.; SICILIANO, S. D. Strain-Specific Ureolytic Microbial Calcium Carbonate Precipitation. Applied And Environmental Microbiology, v.69, n.8, 2003; p. 4901-4909.

[7] PERITO, B.; MARVASI, M.; BARABESI, C.; MASTROMEI, G.; BRACCI, S.; VENDRELL, M.; TIANO, P. A Bacillus subtilis cell fraction (BCF) inducing calcium carbonate precipitation: biotechnological perspectives for monumental stone reinforcement. Journal of Cultural Heritage, v. 15, n. 4, 2014; p. 345-351.

[8] VAN TITTELBOOM, K.; GRUYAERT, E.; RAHIER, H.; DE BELIE, N. Influence of mix composition on the extent of autogenous crack healing by continued hydration or calcium carbonate formation. Construction and Building Materials, v. 37, 2012; p. 349-359.
[9] GOLLAPUDI, U.K.; KNUTSON, C.L.; BANG, S.S.; ISLAM, M.R. A new method for controlling leaching through permeable channels. Chemosphere, v. 30, 1995; p. 695-705.

[10] STOCKS-FISCHER, S.; GALINAT, J.K.; BANG, S.S. Microbiological precipitation of $\mathrm{CaCO}$. Soil Biology and Biochemistry, v. 31, 1999; p. 1563-1571.

[11] TIANO, P.; BIAGIOTTI, L.; MASTROMEI, G. Bacterial biomediated calcite precipitation for monumental stones conservation: methods of evaluation. Journal of microbiological methods, v. 36, n. 1, 1999; p. 139-145.

[12] BACHMEIER, K.L.; WILLIAMS, A.E.; WARMINGTON, J.R.; BANG, S.S. Urease activity in microbiologically-induced calcite precipitation. Journal of Biotechnology, v. 93, 2002; p. 171-181.

[13] DICK, J.; DE WINDT, W.; DE GRAEF, B.; SAVEYN, H.; VANDER MEEREN, P.; DE BELIE, N.; VERSTRAETE, W. Bio-deposition of a calcium carbonate layer on degraded limestone by Bacillus species. Biodegradation, v. 17, 2006; p. 357-367.

[14] RODRIGUEZ-NAVARRO, C.; RODRIGUEZ-GALLEGO, M.; BENCHEKROUN, K.; GONZALEZ-MUNOZ, M.T. Conservation of ornamental stone by Myxococcus xanthus-induced carbonate biomineralization. Applied and Environmental Microbiology, v. 69, 2003; p. 2182-2193.

[15] RAMACHANDRAN, S.K.; RAMAKRISHNAN, V.; BANG, S.S. Remediation of concrete using micro-organisms. ACl Materials Journal, v. 98, 2001; p. 3-9.

[16] DE MUYNCK (1), W.; COX, K.; DE BELIE, N.; VERSTRAETE, W. Bacterial carbonate precipitation as an alternative surface treatment for concrete. Construction and Building Materials, v. 22, n. 5, 2008; p. 875-885.

[17] RAMAKRISHNAN, V. Performance characteristics of bacterial concrete-a smart biomaterial. Proceedings of the First International Conference on Recent Advances in Concrete Technology, Washington, DC, 2007; p. 67-78.

[18] VAN TITTELBOOM, K.; DE BELIE, N.; DE MUYNCK, W.; VERSTRAETE, W. Use of bacteria to repair cracks in concrete. Cement and Concrete Research, v. 40, 2010 p. $157-166$.

[19] WIKTOR, V.; JONKERS, H. M. Quantification of crack-healing in novel bacteria-based self-healing concrete. Cement e Concrete Composites, v. 33, 2011; p. 763-770.

[20] JONKERS, H. M.; THIJSSEN, A.; MUYZER, G.; COPUROGLU, O.; SCHLANGEN, E. Application of bacteria as selfhealing agent for the development of sustainable concrete. Ecological Engineering, v. 36, 2010; p. 230-235.

[21] ACHAL, V.; MUKERJEE, A.; REDDY, M. S. Biogenic treatment improves the durability and remediates the cracks of concrete structures. Construction and Building Materials, v. 48, 2013; p. 1-5.

[22] XU, J.; YAO, W. Multiscale mechanical quantification of selfhealing concrete incorporating non-ureolytic bacteria-based healing agent. Cement and Concrete Research, v. 64, 2014; p. 1-10.

[23] DE KOSTER, S. A. L.; MORS, R. M., NUGTEREN, H. W.; JONKERS, H. M.; MEESTERS, G. M. H.; VAN OMMEN, J. R. Geopolymer Coating of Bacteria-containing Granules for 
Use in Self-healing Concrete. Procedia Engineering, v. 102, 2015; p. 475-484.

[24] LUO, M.; QIAN, C.; LI, R. Factors affecting crack repairing capacity of bacteria-based self-healing concrete. Construction and Building Materials, v. 87, 2015; p. 1-7.

[25] MONTOYA, C.; MARQUEZ, M. A.; LOPEZ, J. M.; CUERVO, C. Characterization of calcite bioprecipitaded by a native Bacillus subtilis isolate. Revista Colombiana de Biotecnologia, v.7, n.2, 2005; p.1-19.

[26] BARABESI, C.; GALIZZI, A.; MASTROMEI, G.; ROSSI, M.; TAMBURINI, E.; PERITO, B. Bacillus subtilis gene cluster involved in calcium carbonate biomineralization. Journal of bacteriology, v. 189, 2007; p. 228-235.

[27] MARVASI, M.; DAVILA-VARQUEZ, Y. C.; MARTINEZ, L. C. Supplemental Materials for Laboratory Activivy to Effectively Teach Introductory Geomicrobiology Concepts to Non-Geology Majors. Journal of Microbiology e Biology Education, v. 14, n. 2, 2013; p. 206-212.

[28] PEI, R., LIU, J.; WANG, S.; YANG, M. Use of bacterial cell walls to improve the mechanical performance of concrete. Cement e Concrete Composites, v. 39, 2013; p. 122-130.

[29] AL-SALLOUM, Y.; ABBAS, H.; SHEIKH, Q. I.; HADI, S.; ALSAYED, S.; ALMUSALLAM, T. Effect of some biotic factors on microbially-induced calcite precipitation in cement mortar. Saudi Journal of Biological Sciences, v. 24, n. 2, 2016; p. 286-294.

[30] DE MUYNCK (2), W.; DEBROUWER, D.; DE BELIE, N., VERSTRAETE, W. Bacterial carbonate precipitation improves the durability of cementitious materials. Cement and Concrete Research, v. 38, 2008; p. 1005-1014.

[31] SCHWANTES-CEZARIO, N.; MEIDEIROS, L. P.; DE OLIVEIRA JR, A. G.; NAKAZATO, G. KOBAYASHI, R. K. T; TORALLES, B. M. Bioprecipitation of calcium carbonate induced by Bacillus subtilis isolated in Brazil. International Biodeterioration \& Biodegradation, v. 123, 2017; p. 200-2005.

[32] ASSOCIAÇÃO BRASILEIRA DE NORMAS TÉCNICAS. Portland Cement - Determination of compressive strength. -NBR 7215, Rio de Janeiro, 1997.

[33] ASSOCIAÇÃO BRASILEIRA DE NORMAS TÉCNICAS. Mortar and concrete - Determination of the tension stregth of cylindrical specimens submitted to diametrical compression. - NBR 7222, Rio de Janeiro, 2011.

[34] ASSOCIAÇÃO BRASILEIRA DE NORMAS TÉCNICAS. Mortars applied on walls and cellings - Determination of elasticity modulus by the ultrasonic wave propagation. -NBR 15630, Rio de Janeiro, 2008.

[35] BRAISSANT, O.; CAILLEAU, G.; DUPRAZ, C.; VERRECCHIA, E. P. Bacterially induced mineralization of calcium carbonate in terrestrial environments: the role of exopolysaccharides and amino acids. Journal of Sedimentary Research, v. 73, n. 3, 2003; p. 485-490.

[36] DUPRAZ, C.; REID, R. P.; BRAISSANT, O.; DECHO, A. W.; NORMAN, R. S.; VISSCHER, P. T. Processes of carbonate precipitation in modern microbial mats. Earth-Science Reviews, v. 96, n. 3, 2009; p. 141-162.

[37] DASKALAKIS, M. I., RIGAS, F., BAKOLAS, A., MAGOULAS, A., KOTOULAS, G., KATSIKIS, I., MAVRIDOU, A. Vaterite bio-precipitation induced by Bacillus pumilus isolated from a solutional cave in Paiania, Athens, Greece. International Biodeterioration \& Biodegradation, v. 99, 2015; p. 73-84.

[38] GHOSH, S.; BISWAS, M.; CHATTOPADHYAY, B. D.; MAN$\mathrm{DAL}, \mathrm{S}$. Microbial activity on the microstructure of bacteria modified mortar. Cement and Concrete Composites, v. 31, n. 2, 2009; p. 93-98.

[39] REDDY, S.; RAO, M.; APARNA, P.; SASIKALA, C. Performance of standard grade bacterial (Bacillus subtilis) concrete. Asian J Civ Eng (Build Housing), v. 11, 2010; p. 43-55.

[40] CHAHAL, N.; SIDDIQUE, R.; RAJOR, A. Influence of bacteria on the compressive strength, water absorption and rapid chloride permeability of fly ash concrete. Construction and Building Materials, v. 28, n. 1, p. 351-356, 2012.

[41] CHAHAL, N.; SIDDIQUE, R. Permeation properties of concrete made with fly ash and silica fume: influence of Ureolytic bacteria.Construction and Building Materials, v. 49, 2013; p. 161-174.

[42] RAMAKRISHNAN, V.; BANG, S. S.; DEO, K. S. (1998, August). A novel technique for repairing cracks in high performance concrete using bacteria. In Proc. of the Int. Conf. on HPHSC, 1998; p. 597-618.

[43] GHOSH, P.; MANDAL, S.; CHATTOPADHYAY, B. D.; PAL, $\mathrm{S}$. Use of microorganism to improve the strength of cement mortar. Cement and Concrete Research, v. 35, n. 10, 2005; p. 1980-1983.

[44] ACHAL, V.; MUKHERJEE, A.; BASU, P. C.; AND REDDY, M. $\mathrm{S}$. "Lactose mother liquor as an alternative nutrient source for microbial concrete production by Sporosarcina pasteurii." J. Ind. Microbiol. Biotechnol., v. 36, n. 3, 2009; p.433-438. 